\title{
REVIEW OF THE MEETINGS OF THE GOVERNMENT OF THE RF IN MAY 2013
}

\author{
M.Goldin
}

In May 2013, at the meetings of the Government of the Russian Federation, the draft law which assigns the state authorities of constituent entities of the Russian Federation the right to set the criteria of need of individual categories of people in social support with the principle of target orientation taken into account was discussed among other issues.

On May 16, at the meeting of the Government of the Russian Federation, federal draft law on Amendment of Article 26.3 and Article 26.3.1 of the Federal Law on the General Principles of Organization of Legislative (Representative) and Executive State Authorities of Constituent Entities of the Russian Federation was discussed.

By the above draft law, in Federal Law No. 184-FZ of October 6, 1999 on The General Principles of Organization of Legislative (Representative) and Executive State Authorities of Constituent Entities of the Russian Federation the right is granted to state authorities of constituent entities of the Russian Federation to set the criteria of need of individual categories of people in social support with the principle of target orientation taken into account.

At present, state authorities of the Russian Federation are vested with powers to organize provision of social support to the following categories of people:

- elderly people and disabled persons;

- people who are in a difficult life situation;

- orphan children;

- neglected children;

- children left without parents' care (except for children who study at federal educational establishments);

- labor veterans;

- persons who worked in the rear during the Great Patriotic War of 1941-1945;

- families with children (including large families and single parents);

- victims of political reprisals;

- low-income people, including that at the expense of provision of target-oriented subsidies to local budgets for payment of public transport allowances.

Also, social support can materialize in compensation of costs of municipal entities in connection with provision under laws of a constituent entity of the Russian Federation of privileges to individual categories of people, including privileges as regards payment of communication services and organization of provision to people of subsidies for payment of housing and utilities services.

In addition to the above, in accordance with Article 26.3.1. (5) state authorities of a constituent entity of the Russian Federation are in a position to provide at the expense of the budget of the constituent entity of the Russian Federation additional measures of social support and social assistance to individual categories of people no matter whether provisions which establish the above right exist in federal laws.

As constituent entities of the Russian Federation have already been granted vast authorities as regards rendering of assistance to different categories of people, it seems logical to supplement those authorities with a possibility to provide that aid with a target orientation factor taken into account.

The draft law was approved and submitted to the State Duma of the Russian Federation. 